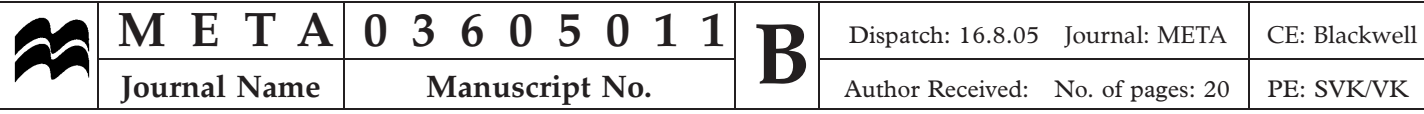

(C) Metaphilosophy LLC and Blackwell Publishing Ltd. 2005.

Published by Blackwell Publishing Ltd, 9600 Garsington Road, Oxford OX4 2DQ, UK, and 350 Main Street, Malden, MA 02148, USA

METAPHILOSOPHY

Vol. 36, No. 5, October 2005

0026-1068

\section{A METAPHILOSOPHICAL DILEMMA FOR EPISTEMIC EXTERNALISM}

\author{
PIERRE LE MORVAN
}

\begin{abstract}
In this article I argue that the prevalence of intersubjective disagreement in epistemology poses a serious problem for Epistemic Externalism. I put the problem in the form of a dilemma: either Epistemic Externalism is not a complete account of epistemic justification or it's implausible to claim that the belief that Epistemic Externalism is true is itself an externalistically justified belief.
\end{abstract}

Keywords: epistemic justification, Epistemic Externalism, Epistemic Internalism, intersubjective disagreement.

\section{Introduction}

From a metaphilosophical standpoint, we may distinguish between the following two broad kinds of claim that philosophical theories may contain: reflexive and nonreflexive claims.

A reflexive claim applies to the theory containing it, though not necessarily only to the theory containing it. Consider, for example, a philosophical theory of meaning. If such a theory contains the claim that a certain criterion $C$ determines what counts as meaningful, then, on pain of refutation of the theory, one should be able to state $C$ in such a way as to satisfy $C$. A standard objection to Verificationism illustrates this point, the objection being that the Verification Criterion of Meaning fails to pass its own test for having meaning.

A nonreflexive claim does not apply to the theory containing it. For example, Hanslick's theory of musical beauty contains claims about the nature of the musically beautiful that do not apply to the theory itself, for Hanslick's theory is not itself a piece of music. Whatever objections we may lodge against it, we cannot fault this theory for failing to pass its own criteria for what counts as musically beautiful.

However, even if a claim is (strictly speaking) nonreflexive in the sense delineated above, it may still be what we may call doxastically reflexive, in the sense that it applies to beliefs about the theory containing it. For instance, theories about the nature of belief and theories about the nature of the epistemic justification of belief contain claims that are doxastically 
reflexive because they apply to beliefs about these very theories. Accordingly, an important way of criticizing a theory of this sort is to argue that it does not satisfy a condition specified or implied by one of its own doxastically reflexive claims.

In this light, I raise in this article a metaphilosophical (or metaepistemological) dilemma for Epistemic Externalism ("Externalism" for short), a dilemma concerned with the epistemic justification of believing that this theory is true. For ease of reference, let's call this belief "the Externalist Belief." Because I'm generally sympathetic to Externalism, my intent in raising the dilemma is not to refute the theory. Rather, it's to expose a problem for Externalism that its defenders need to address, one that has yet to receive the attention it deserves. The dilemma in question may be summarized as follows:

1. Suppose that the Externalist Belief is (epistemically) justified.

2. The Externalist Belief is either externalistically justified or it is not externalistically justified.

3. If it is not, then Epistemic Externalism is not a complete account of epistemic justification.

4. Even if it is, it's implausible to claim that the Externalist Belief is externalistically justified.

5. Hence, either Epistemic Externalism is not a complete account of epistemic justification or it's implausible to claim that the Externalist Belief is externalistically justified. ${ }^{1}$

The following structure informs the rest of this article. In section 2, I do some background setting by delineating the internalist/externalist divide in theories of epistemic justification ("justification" for short), and by raising the important issue of intersubjective agreement. In section 3 , I argue for the dilemma's third premise and in section 4, I argue for its fourth. (I argue only for the third and fourth premises, because the first two do not need to be defended for the purposes of this article, and because the argument is logically valid.) I then respond to some important objections in section 5 and conclude in section 6 by proposing a way of reconciling Epistemic Internalism and Externalism, thereby affirming significant insights from each.

\section{Epistemic Internalism, Epistemic Externalism, and Intersubjective Agreement}

Epistemic Internalism and Externalism, as these terms are understood here, are accounts of the justification of beliefs in the state sense (that is,

\footnotetext{
${ }^{1}$ Readers may substitute "positive epistemic status" for "epistemic justification" and "has externalist positive epistemic status" for "is externalistically justified" if they so prefer.
} 
in the sense of a belief's being justified), not in the activity sense (that is, in the sense of someone justifying a belief).

Although it is somewhat contentious to write of the internalist/ externalist distinction, given the number of different ways that Epistemic Iternalism and Externalism are distinguished in the literature, Conee and Feldman 2001 present a very strong case that theirs is the most basic or general way of drawing an internalist/externalist distinction. Accordingly, I shall use their internalist/externalist distinction for the purposes of this article, the general points of which may be applied mutatis mutandis to other ways of distinguishing between Epistemic Internalism and Externalism.

Conee and Feldman distinguish two main characterizations of Epistemic Internalism ("Internalism" for short) prevalent in the literature; they call these "Accessibilism" and "Mentalism," respectively. Accessibilism, as they put it, "holds that the epistemic justification of a person's belief is determined by things to which the person has some special sort of access. BonJour calls this access a suitable awareness. Audi says that the access is through 'introspection or reflection.' Others say that the access must be "direct"' (2001, 233).

Mentalism, as they describe it, holds that a belief is justified only by things internal to a person's mental life: the justification of a person's belief strongly supervenes only on the person's occurrent and dispositional mental states, events, and conditions (2001, 233-34).

On the assumption that the special access posited by Accessibilism is only to mental states, events, and conditions, we can think of Mentalism as the genus of which Accessibilism is a species. For the purposes of this article, Internalism may be understood under either of these characterizations, and epistemic internalists ("internalists" for short) may be understood as those adhering to Mentalism, or to Accessibilism more specifically. $^{2}$

Epistemic externalists ("externalists" for short) reject these internalist - whether mentalist or accessibilist - strictures on justification. They claim instead that a belief's justification is a function of its being produced in the right way - for instance, in a reliably truth-conducive way-as a matter of objective fact, even if this justification is not one to which one has special access, or is not internal to one's mental life. ${ }^{3}$ For ease of reference, let's call this claim "Epistemic Externalism" (or "Externalism" for short), use "reliable" as short for "reliably truth-conducive," and use

2 Contemporary internalists include Conee and Feldman (1985, 2001), Feldman (1985, 2000), Foley (2001), Audi (1989, 2001), Chisholm (1988, 1989), Lehrer (1990), Pollock (1986), BonJour $(1985,2003)$, and many others. Alston (1989) offers an internalism with externalist features.

${ }^{3}$ Contemporary externalists include Goldman (1979, 1986, 2001), Plantinga (1993a, 1993b, 2000), Alston (1995), Armstrong (1973), Bach (1985), Dretske (1981), Swain (1981), Nozick (1981), Sosa (2003), and many others. 
"reliably produced" as short for "produced in a reliably truth-conducive manner." In connection with Externalism, the following four points merit notice.

First, an important realist implication of Externalism is that, in principle, there can be beliefs whose justification is cognitively transcendent; that is, beliefs the justification of which no human being (including the believer) may be in a position to ascertain. Externalism is similar in this way to a realist account of truth according to which there can, in principle, be cognitively transcendent truths; that is, truths that no human being may be in a position to ascertain.

Second, while externalists agree that a belief's justification is a function of its being produced in the "right" (or "proper") way, they differ on how to characterize this "right" way. Though not all of them take a belief's being reliably produced to be a sufficient condition for whether the belief is justified, reliable truth conducivity plays an important role in all extant externalist accounts of the justification of belief.

Third, the way that Conee and Feldman distinguish Externalism from Internalism does not entail that Internalism is incompatible with holding that a belief's being reliably produced is a necessary condition for its being justified. ${ }^{4}$ On their distinction, what demarcates Externalism from Internalism is the former's rejection of the latter's accessibilist or mentalist strictures on justification.

Fourth, a distinction needs to be drawn between (i) a belief's being produced by a reliable doxastic process and (ii) a belief's being reliably produced by a reliable doxastic process. Although all instances of (ii) are instances of (i), it does not follow that just because a belief is produced by a reliable doxastic process, it is reliably produced by this process.

As an illustration of this point, consider the paradigmatic examples of reliable doxastic processes that externalists typically adduce: perception, memory, and elementary logical and mathematical reasoning. Although externalists typically take these to be reliable in standard cases, none takes them to be perfectly reliable in all cases, on the good ground that we sometimes generate false beliefs when employing such processes. A process that is reliable under some conditions or for some subject matters may be unreliable under other conditions or for other subject matters.

Take perception, or vision more specifically. Even if generally reliable under many lighting conditions, vision may not be so under conditions of (say) obscure lighting. Or even if reliable with respect to relatively near mid-size physical objects, vision may not be so with respect to tiny objects or far away objects.

Take memory. Although it may be generally reliable about events that happened today, it may be far less reliable about events that happened five years ago; and though it may be generally reliable when used to recall

${ }^{4}$ I owe this point to William P. Alston. 
seven or fewer items, it may be far less so when used to recall eight or more items.

Significant intersubjective disagreement found in the beliefs produced by a generally reliable doxastic process, such as perception or memory, strongly suggests that the process is being used under conditions or for subject matters where the process is not operating in a reliable manner. For ease of reference, let's call a reliable doxastic process operating in a reliable manner an "R-process."

Having made a number of clarifications concerning Internalism and Externalism, let me now also clarify my use of the term plausibility by distinguishing between first-person and third-person plausibility. By "firstperson plausibility" I mean plausibility to a particular person or from a particular point of view, whereas by "third-person plausibility" I mean plausibility to an impartial observer or from an impartial point of view. First-person plausibility is subjective and tends to be variable, whereas third-person plausibility is (ideally) objective or at least intersubjective and tends to be invariable. Plenty of claims (for example, that there are alien abductions, that there was a conspiracy to kill JFK, and the like) that may be plausible from a first-person perspective (depending on the person in question, of course) may be implausible from a third-person perspective.

Notice that when philosophers argue for, and seek to convince others of, the plausibility of a claim, the plausibility they are after is generally third-person plausibility. For there is little point in arguing, or in trying to convince others, that a claim is plausible (merely) from one's own perspective. Accordingly, when I write of plausibility or implausibility in this article, including with regard to the Metaphilosophical Dilemma I am explaining and defending here, I mean them in the third-person sense, not merely in the first-person sense.

With these clarifications made, I shall now suppose, for the sake of argument, that Externalism is quite plausible in standard cases where beliefs directly result from basic doxastic processes, such as perceiving, recalling from memory, or engaging in elementary forms of mathematical and logical reasoning. In these standard cases, we find a notable degree of intersubjective agreement; that is, when one cognitive agent employs one of these basic doxastic processes, the beliefs he or she will acquire will generally agree with, in the sense of being similar or even identical in content to, those beliefs formed by another cognitive agent using this doxastic process in similar situations.

In light of this intersubjective agreement, I shall make the following two assumptions, also for the sake of argument. First, the best explanation for the intersubjective agreement we find in the beliefs resulting from the aforementioned processes is that the latter are R-processes in these standard cases. Second, the beliefs formed via such R-processes in these cases generally enjoy the sort of justification that externalists attribute to them. Let's call this "externalist justification." 
Given these assumptions about intersubjective agreement ("IA" for short), I shall propose the following two criteria for assessing the plausibility of claims concerning the reliable truth-conducivity of doxastic processes and externalist justification.

According to what we may call the "IA Criterion for Reliability," the more intersubjective agreement we find in the beliefs resulting from a doxastic process, the more plausible it is to claim that the latter is an Rprocess; conversely, the less intersubjective agreement we find in such beliefs, the less plausible it is to make such a claim.

According to what we may call the "IA Criterion for Externalist Justification," the more intersubjective agreement we find in the beliefs resulting from a doxastic process, the more plausible it is to claim that they enjoy externalist justification; conversely, the less intersubjective agreement we find in such beliefs, the less plausible it is to make such a claim.

With reference to these two criteria, the following clarifications are in order. I propose them as criteria of the prima facie plausibility (or implausibility) of claiming that a doxastic process is an R-process or of claiming that certain beliefs enjoy externalist justification. Being prima facie criteria, they are subject to being overridden by other considerations. For instance, if there is good reason to suppose that the high level of intersubjective agreement found in beliefs resulting from a particular doxastic process is best explained by factors other than this process's being an R-process (for example, social pressures to conform, brainwashing, collective self-deception, and so on), such reasons may override the prima facie plausibility of claiming that this doxastic process is an Rprocess or that the beliefs resulting from it enjoy externalist justification.

Furthermore, as criteria of prima facie plausibility, they leave open the possibility that there may be, as a matter of objective fact, R-processes where little, if any, intersubjective agreement is to be found, because of their relative rarity. For instance, suppose that $\mathrm{S}$ is a tetrachromat with a remarkable ability to pick out colors indiscernible to others. Even if one didn't find that others agree with S's color beliefs - because they lack S's discriminatory abilities and the special doxastic process $S$ employs-it may still be the case that S's color beliefs resulted from an R-process and so these beliefs are externalistically justified. A doxastic process's rarity does not preclude it from being an R-process.

However, I shall take it to be the case that, in the absence of overriding considerations, the less intersubjective agreement found in beliefs resulting from a doxastic process, the more implausible tout court it is to claim that this process is an R-process and that the beliefs resulting from it enjoy externalist justification.

Accordingly, I shall propose a test for the plausibility of claiming that a doxastic process is an R-process and that the beliefs resulting from it enjoy externalist justification, a test that applies when one does not find a 
(reasonably) high level of intersubjective agreement in the beliefs resulting from a doxastic process. This test is that there should be overriding considerations that account for this lack.

So far, our discussion of plausibility criteria has focused on beliefs produced by the same doxastic process. But the following possible situation also merits our attention. Suppose that one group of subjects employs a certain doxastic process, call it "A," and that another group of subjects employs another, call it "B." Suppose that we find a high level of intersubjective agreement in the beliefs resulting from A and a high level of intersubjective agreement in the beliefs resulting from B. Suppose in addition, however, that the beliefs resulting from $\mathrm{A}$ are incompatible with the beliefs resulting from $\mathrm{B}$.

The problem we face now is that, since the output of A clashes with the output of B, the presence of this clash defeats the prima facie plausibility of claiming that (i) both $\mathrm{A}$ and $\mathrm{B}$ are R-processes and that the beliefs resulting from both $\mathrm{A}$ and $\mathrm{B}$ are externalistically justified, and of claiming that (ii) A in particular but not B is an R-process (or vice versa), and that the beliefs resulting from $\mathrm{A}$ in particular but not from B are externalistically justified (or vice versa).

Claim (i)'s prima facie plausibility is defeated, because the beliefs resulting from $\mathrm{A}$ and from $\mathrm{B}$ are incompatible, and so $\mathrm{A}$ and $\mathrm{B}$ cannot both be R-processes. Let's call this kind of defeater of prima facie plausibility a "conjoint defeater."

Claim (ii)'s prima facie plausibility is also defeated, for when the output of one doxastic process clashes with another's, this clash constitutes a defeater of the prima facie plausibility of claiming that one in particular, but not the other, is an R-process. Let's call this kind of defeater of prima facie plausibility a "disjoint defeater."

As an illustration of a disjoint defeater, consider this example. Suppose there were a world where people were either brown-eyed or blue-eyed, and where brown-eyed people and blue-eyed people differed regularly and significantly in their beliefs about the colors of physical objects. Even if, as a matter of objective fact, it were the case that (say) the color beliefs of the brown-eyed people, but not the blue-eyed, were produced by an Rprocess and were therefore externalistically justified, the very presence of such a clash would constitute a disjoint defeater of the prima facie plausibility of claiming that the color beliefs of the brown-eyed in particular but not the blue-eyed were produced in this manner and were so justified. Its prima facie plausibility defeated, the claim would be implausible tout court unless there were overriding considerations for thinking that the color beliefs of the brown-eyed people in particular but not the blue-eyed were produced by an R-process and so externalistically justified.

Consequently, I shall propose an additional test for the plausibility of claiming that a doxastic process is an R-process and that the beliefs 
resulting from it enjoy externalist justification, a test that applies when one finds that the beliefs resulting from a doxastic process of one group are incompatible with the beliefs resulting from a doxastic process of another. This test is that there should be overriding considerations that account for why one doxastic process but not the other is an R-process.

So much for background. In the next two sections, I return to the dilemma with which we began, and argue for its two key premises, namely, the third and fourth.

\section{Externalism as an Incomplete Theory}

If the Externalist Belief is not externalistically justified, then Externalism cannot be a complete account of justification. For consider the question of what sort of justification, if any, the Externalist Belief enjoys. If Externalism does not account for this belief's justification, then, on the assumption that it is justified, this justification will have to be explained, provided it can be explained at all, in terms of a nonexternalist account_an ironic result.

\section{The Implausibility of Claiming that the Externalist Belief is Externalistically Justified, even if It Is so Justified}

The argument for my fourth premise may be summarized as follows:

1. There is widespread intersubjective disagreement in epistemology, including over whether Externalism is true.

2. The Externalist Belief results from either a doxastic process that produces beliefs that do not enjoy much intersubjective agreement or from a doxastic process whose output clashes with that of another doxastic process.

3. If the Externalist Belief results from either a doxastic process that produces beliefs that do not enjoy much intersubjective agreement or from a doxastic process whose output clashes with that of another doxastic process, then, even if it is externalistically justified, it's implausible to claim that the Externalist Belief is so justified.

4. Hence, even if it is externalistically justified, it's implausible to claim that the Externalist Belief is so justified.

Is this argument sound? Since it is logically valid, my defense of the argument will consist in defending its three premises.

\subsection{Defense of the First Premise}

Any honest epistemologist has to concede that there is widespread intersubjective disagreement in epistemology, including over whether Externalism is true. In fact, we all know that it is a rather embarrassing fact about epistemology — and philosophy more generally — that there is 
widespread intersubjective disagreement concerning almost every substantive issue. Moreover, if the history of epistemology serves as any guide, it's unlikely that this widespread intersubjective disagreement will disappear and that widespread intersubjective agreement will emerge concerning the truth of Externalism. Of course, this could happen, but there are few, if any, signs that it will happen in the foreseeable future.

\subsection{Defense of the Second Premise}

Consider the many externalists who hold the Externalist Belief and the many internalists who believe that Internalism is true (the "Internalist Belief" for short). Their beliefs did not arise by magic or at random, or so I shall assume. Hence, they presumably resulted from some doxastic process, whether endogenous or acquired. (Such a doxastic process can be thought of as a high-level doxastic process that takes beliefs from other doxastic processes as input and yields epistemological beliefs as output.) Now, either these beliefs arose from the same doxastic process (one common to externalists and internalists) or they did not.

Suppose they resulted from a doxastic process common to both externalists and internalists. If so, then this doxastic process results in beliefs where intersubjective disagreement prevails, as glaringly evidenced by the fact that internalists hold the Internalist Belief and externalists hold the Externalist Belief.

Suppose instead that these beliefs did not arise from the same doxastic process. If so, they presumably arose from two distinct doxastic processes. Let's say that the Externalist Belief resulted from a doxastic process common only to externalists, and that the Internalist Belief resulted from a doxastic process common only to internalists. Gone now is the intersubjective disagreement found in beliefs resulting from the same putative doxastic process. For after all, internalists agree among themselves that Internalism is true and externalists agree among themselves that Externalism is true. However, now there is intersubjective disagreement between beliefs resulting from two distinct doxastic processes, as evidenced by the Externalist Belief's incompatibility with the Internalist Belief.

It follows from this reasoning that the Externalist Belief results from either a doxastic process that produces beliefs that do not enjoy much intersubjective agreement or from a doxastic process whose output clashes with that of another doxastic process. And that is precisely what is claimed in the second premise of the argument in question.

\subsection{Defense of the Third Premise}

As we have seen, on Externalism, a belief is justified as a matter of objective fact, and in principle a belief may be externalistically justified, 
even if the believer or others are not in a position to ascertain that it is so justified. Let's suppose, for the sake of argument, that the Externalist Belief is externalistically justified. As we discussed above in our defense of the second premise, the Externalist Belief results from either a doxastic process that produces beliefs that do not enjoy much intersubjective agreement or from a doxastic process whose output clashes with that of another doxastic process.

If the Externalist Belief arose from a doxastic process that produces beliefs that do not enjoy much intersubjective agreement, then it's prima facie implausible to claim that this belief resulted from an R-process and is externalistically justified, even if it is so justified. This is because even if it happens to be externalistically justified (and so justified as a matter of objective fact), claiming that it is so justified runs afoul of the IA Criteria for Reliability and for Externalist Justification.

Could this prima facie implausibility be overridden by other considerations? The problem here is that it's far from obvious what these overriding considerations would be. For consider how dubious it seems to claim that externalists are blessed with special epistemological abilities or access (privileged or otherwise) to epistemological facts or data unavailable to internalists (or vice versa). It also seems dubious to claim that the belief of one group but not the other can be explained away as the result of brainwashing, or wishful thinking, or dimwittedness, or sloppy reasoning, or collective self-deception, or bad teaching, or the like. In any case, I challenge those who think there are such overriding considerations to specify and defend them.

In the absence of such overriding considerations, it's not just prima facie implausible but implausible tout court to claim that the Externalist Belief resulted from a reliably truth-conducive doxastic process and is externalistically justified.

Suppose instead that the Externalist Belief results from a doxastic process common only to externalists (call this "EDP"), and that the Internalist Belief results from a distinct doxastic process common only to internalists (call this "IDP"). The problem now is that the Externalist Belief results from the EDP, whose output clashes with the output of the IDP.

The presence of this clash constitutes a conjoint defeater of the prima facie plausibility of claiming that (i) both the EDP and the IDP are Rprocesses and that the beliefs resulting from both the EDP and IDP are externalistically justified, and it constitutes a disjoint defeater of the prima facie plausibility of claiming that (ii) the EDP in particular but not the IDP is an R-process (or vice versa), and that the beliefs resulting from the EDP but not from the IDP are externalistically justified (or vice versa).

That is, a conjoint defeater undercuts the prima facie plausibility of claim (i), because the beliefs of the EDP and the IDP are incompatible, and so the EDP and the IDP cannot both be R-processes. A disjoint 
defeater undercuts the prima facie plausibility of claim (ii), for when the output of one doxastic process clashes with that of another, this clash constitutes a defeater of the prima facie plausibility of claiming that one in particular, but not the other, is an R-process. Their prima facie plausibility defeated, these claims are implausible tout court in the absence of overriding considerations.

Moreover, with regard to possible considerations that would override these defeaters, it seems dubious once again to claim that externalists are endowed with special epistemological abilities or access (privileged or otherwise) to epistemological facts or data unavailable to the internalists (or vice versa). It also seems dubious once again to claim that the belief of one group but not the other can be explained away as the result of brainwashing, or wishful thinking, or dimwittedness, or sloppy reasoning, or collective self-deception, or bad teaching, or the like. And in the absence of overriding considerations, the implausibility of claiming that the Externalist Belief is externalistically justified is not only prima facie but also tout court, even if the Externalist Belief happens to be so justified.

In sum, if the Externalist Belief results from either a doxastic process that produces beliefs that do not enjoy much intersubjective agreement or from a doxastic process whose output clashes with that of another doxastic process, then even if it is externalistically justified it's implausible to claim that the Externalist Belief is so justified. And this is precisely what is claimed in the third premise of the argument above.

\subsection{Taking Stock}

If my reasoning above is sound, the third and fourth premises of the metaphilosophical dilemma for Externalism are true. Since the first and second premises do not stand in need of defense for the purposes of this article, and since the argument is logically valid, I conclude that, on the assumption that the Externalist Belief is justified, either Epistemic Externalism is not a complete theory of epistemic justification or it's implausible to claim that the Externalist Belief is externalistically justified, even if it is so justified. In the next section, I consider and reply to some objections.

\section{Some Objections and Replies}

At least seven objections to my case deserve attention.

\subsection{Objection}

Why should externalists be concerned by your putative dilemma? For after all, Externalism offers an account of justification that takes the latter to be an objective matter, and you yourself concede that, as a matter of objective fact, the Externalist Belief may be externalistically justified. 
Reply: Even if, as a matter of objective fact, the Externalist Belief is externalistically justified, there remains the question of the plausibility of claiming that it is so justified. Externalism is, after all, a philosophical theory, and in assessing a theory, we consider, among other things, what reasons or grounds there are for believing it. If it's implausible to claim that the Externalist Belief is externalistically justified, then this poses a serious problem for externalists insofar as they seek to offer a philosophical defense of their theory and to convince others to believe it. For the implausibility of claiming that the Externalist Belief is externalistically justified undercuts their defense. Consider this analogy: if a realist theory of truth was true as a matter of objective fact but was such that it was implausible to claim that this theory was so true, this should be of serious concern to its defenders. Though Externalism is increasingly popular, no externalist in the literature has, at least as of yet, addressed the problem that intersubjective disagreement poses for plausibly claiming that Externalism is true.

What's more, if the Externalist Belief is not externalistically justified, and so nonexternalistically (and so presumably internalistically) justified if it is justified at all, this should also be of serious concern to externalists insofar as they think that Externalism offers a complete account of justification.

\subsection{Objection}

Your argumentation for the putative metaphilosophical dilemma for Externalism is predicated on certain criteria of plausibility that link the plausibility of claims about reliable truth-conducivity and externalist justification to intersubjective agreement. But why should any externalist accept such criteria?

Reply: When philosophers write articles and books and make presentations in defense of a theory, they seek to convince others to believe it by adducing reasons and arguments. And in seeking to convince others to believe a theory, they want at least to show that it's plausible. When externalists argue for the plausibility of Externalism, they typically adduce perception, memory, and elementary mathematical and logical reasoning as paradigmatic examples of $\mathrm{R}$-processes that produce beliefs that are (externalistically) justified. I think that externalists are right about these paradigmatic cases. But notice that a key feature that such doxastic processes have in common is that they produce beliefs where we find a high degree of intersubjective agreement. And it is, I submit, precisely because of this high degree of intersubjective agreement that externalists plausibly infer that these doxastic processes are in standard cases R-processes. If one rejects intersubjective agreement as a good (even if defeasible) indicator or sign of belief production by an R-process and of externalist justification, then one needs to provide a better alternative. As of yet, no externalist has done so. 


\subsection{Objection}

You contend that if the Externalist Belief and the Internalist Belief result from a doxastic process common both to externalists and to internalists, then "this process results in beliefs where intersubjective disagreement prevails, as glaringly evidenced by the fact that internalists hold the Internalist Belief and externalists hold the Externalist Belief." If it were the case that this process produced only these two beliefs (or more generally, only epistemological or philosophical beliefs), then it would indeed be a process that resulted in beliefs where intersubjective disagreement prevails.

But suppose that this process produces not just the Internalist Belief and the Externalist Belief (or not just epistemological or philosophical beliefs) but also a wide variety of other beliefs, and that these other beliefs are ones where overall we find a great deal of intersubjective agreement. For instance, suppose that this process is one of abductive inference; that is, a process of inference to the best explanation. Evidential beliefs serve as input to this process, and its output are beliefs purporting to provide a best explanation of these evidential beliefs. The input beliefs to this process are themselves the output of such processes as perception, memory, introspection, and philosophical intuition. On this supposition, such philosophical beliefs as the Internalist Belief and the Externalist Belief are outputs of the same process that produces scientific and commonsense beliefs insofar as they are abductive.

Accordingly, one could plausibly argue that the outputted beliefs of this process exhibit much intersubjective agreement; for even if philosophical beliefs do not exhibit such agreement, perhaps most commonsense and scientific beliefs do. Moreover, a pleasing feature of this view is that, on it, we don't have to suppose that philosophers employ a doxastic process that other people don't have; rather, philosophers employ a doxastic process that everybody has, but philosophers employ it with regard to subject matters that others don't think about or at least don't think much about. Though the process is the same as it is with commonsense and scientific beliefs, when it's used to produce philosophical beliefs, it's being used on subject matters that differ from the subject matters of commonsense and scientific beliefs.

In brief, even if the Externalist Belief and the Internalist Belief result from a doxastic process common to both externalists and to internalists, it could still be the case that these two beliefs result from a doxastic process that produces beliefs where intersubjective agreement prevails overall, and thus the process could be generally reliable. ${ }^{5}$

\footnotetext{
${ }^{5}$ I owe this objection to a Metaphilosophy referee who cited Goldman and Pust (2002) as a source for the view that philosophical beliefs may result from the same process that produces scientific beliefs.
} 
Reply: In response to this objection, I offer two main rejoinders.

First, if the objector's supposition were true, one of its interesting implications would be that the Internalist Belief and the Externalist Belief would be on par (other things being equal) in terms of whatever externalist justification they enjoy. That is, if the Externalist Belief and the Internalist Belief both result from a doxastic process common to externalists and to internalists, and this process is one of abductive inference that also generates commonsense and scientific beliefs, then the Internalist Belief would accrue whatever externalist justification the Externalist Belief accrues from being produced by this process insofar as the latter is reliable. This is an awkward implication for Externalists who seek to argue for the Externalist Belief and against the Internalist Belief.

Second, recall our distinction between (i) a belief's being produced by a reliable doxastic process and (ii) a belief's being reliably produced by a reliable doxastic process. Intersubjective disagreement found in beliefs produced by a generally reliable doxastic process, such as perception or memory, strongly suggests that the process is being used under conditions or for subject matters where the process is not operating in a reliable manner. By parity of reasoning, then, even if we suppose that the Internalist Belief and the Externalist Belief (or epistemological or philosophical beliefs more generally) resulted from the same generally reliable doxastic process, the presence of the kind of intersubjective disagreement discussed in this article strongly suggests that the process that produced them is not operating in a reliable manner. Hence, the Internalist and Externalist Beliefs would be on par in accruing little or no externalist justification.

\subsection{Objection}

Let's return to the possibility that that Externalist Belief results from a doxastic process common only to externalists, namely, the EDP, and that the Internalist Belief results from a distinct doxastic process common only to internalists, namely, the IDP. You contend that, if this were the case, a problem for externalists would be that the clash in output between the EDP and the IDP would constitute a conjoint defeater of the prima facie plausibility of claiming that both the EDP and the IDP are reliably truthconducive, and would also constitute a disjoint defeater of the prima facie plausibility of claiming that the EDP in particular, but not the IDP, is reliably truth-conducive.

Suppose that's right. Even so, don't externalists provide overriding considerations for the plausibility of claiming that the Externalist Belief is reliably produced and so is externalistically justified? For externalists argue for the Externalist Belief and against the Internalist Belief. And in doing so, they are in effect arguing that the Externalist Belief is supported by good, rigorous reasoning (and so presumably produced by an R- 
process), whereas the Internalist Belief is "supported" merely by bad or sloppy reasoning (and so presumably produced by an unreliable doxastic process). As an anonymous referee for Metaphilosophy, to whom I owe this objection, put it:

[G]iven that the externalist is persuaded by his arguments for the Externalist Belief and against the Internalist Belief, and given that he rejects the internalist's arguments for the Internalist Belief and against the Externalist Belief, it seems plausible for the externalist to claim that the Externalist Belief is caused by a reliably truth-conducive process, and the Internalist Belief is not. To put the point another way: from the externalist's point of view, the claim that the Externalist Belief is externalistically justified will be just as plausible as Externalism itself. ${ }^{6}$

In sum, even if the clash in output between the EDP and the IDP constitutes the sort of conjoint defeater and disjoint defeater you describe, externalists, by arguing for the Externalist Belief and against the Internalist Belief, provide sufficient considerations to override these defeaters.

Reply: To my knowledge, no externalist has yet directly discussed the problem for the plausibility of claiming that the Externalist Belief is externalistically justified, posed by the prevalence of intersubjective disagreement in epistemology, let alone directly offered considerations overriding the conjoint and disjoint defeaters I discussed above. Nor, to my knowledge, has any externalist ever claimed that the Externalist Belief is a result of an R-process unique to externalists and so externalistically justified. But in any case, it is true, of course, that externalists argue for the Externalist Belief and against the Internalist Belief.

To answer this objection, we must hearken back to the distinction between first-person and third-person plausibility. ${ }^{7}$ I concede that, as the referee put it well, "from the externalist's point of view, the claim that the Externalist Belief is externalistically justified will be just as plausible as Externalism itself." But the plausibility I am concerned with in this article is not the first-person plausibility (for externalists) of claiming that the Externalist Belief is externalistically justified but rather the third-person plausibility of such a claim. (Incidentally, externalists, given their emphasis on objective justification, should be quite comfortable with the notion of third-person plausibility or implausibility.)

Even if, by arguing for the Externalist Belief and against the Internalist Belief, externalists in effect provide considerations against the disjoint and conjoint defeaters discussed above, the question remains whether these are sufficiently strong to count as overriding considerations, given that internalists also argue for the Internalist Belief and against the

\footnotetext{
${ }^{6}$ Quoted from a referee's report.

${ }^{7}$ In fairness to the referee, I had not made this distinction explicit until presented with this objection.
} 
Externalist Belief. And at this juncture in the history of epistemology, an impartial observer would most likely conclude that neither externalists nor internalists have reached what we might call, to adapt to our purposes an expression Goldman $(2002,148)$ uses in the context of discussing trust in expertise, "dialectical superiority"; that is, a position where one side is able to offer defeaters or rebuttals to the grounds or reasons adduced by the other side, and the other side is unable to do likewise. (To use an admittedly imperfect analogy, it's not as if externalists today have reached a position of dialectical superiority over internalists akin to, say, the dialectical superiority reached by oxygen chemists over phlogiston chemists by about 1840). Accordingly, despite my own sympathy for externalism, I submit that it is premature at best for its proponents to claim that they have adduced considerations sufficiently strong to override the conjoint and disjoint defeaters discussed above.

\subsection{Objection}

The situation in contemporary epistemology may be akin to situations often found in immature sciences where adherents of different schools of thought disagree until one school produces an intellectual achievement unmatched by its rivals and thereby achieves ascendancy. You have not shown that something similar will not happen with Externalism.

Reply: One cannot rule out that this possibility might be realized sometime in the future. But it does not seem at present that externalists (or internalists) can point to an intellectual achievement of theirs significant enough clearly to warrant the ascendancy of Externalism over Internalism (or vice versa) in the foreseeable future. In the meantime, externalists would do well to address the problem that intersubjective disagreement poses for the defense of their theory.

\subsection{Objection}

You have not established that there are no overriding considerations that would account for the Externalist Belief's being externalistically justified despite the prevalence of intersubjective disagreement in epistemology.

Reply: I cannot prove or establish that there are none. For all I know, perhaps Alvin Goldman or Alvin Plantinga or other externalists are so constituted that their Externalist Belief does indeed result from an Rprocess and is externalistically justified as a result. Perhaps externalists have a special kind of epistemological R-process that internalists do not share. Perhaps externalists are to epistemological beliefs what tetrachromats are to color beliefs. Howbeit, the onus is on the defenders of Externalism to adduce considerations sufficiently strong to overcome the problem for the justification of the Externalist Belief posed by the prevalence of intersubjective disagreement in epistemology, and so far none is in a position plausibly to claim to have done so. 


\subsection{Objection}

Isn't the intersubjective disagreement to which you refer just as serious a problem for Internalism?

Reply: In a word, no. On Internalism, the justification of a person's belief supervenes solely on the person's occurrent and dispositional mental states, events, and conditions. Now consider the justification of the Internalist Belief; for instance, the belief held by internalist $S$ that Internalism is true. So long as this belief is justified by states, events, or conditions internal to S's mind, S's belief is internalistically justified, even if it does not enjoy intersubjective agreement with what externalists believe. Accordingly, if the Internalist Belief held by $\mathrm{S}$ has the sort of intrasubjective features (such as coherence with other things $\mathrm{S}$ believes or knows, intuitive self-evidency, being formed in an epistemically permissible or nonculpable manner, and the like) posited by Mentalism or Accessibilism, then it is plausible for $\mathrm{S}$ to claim that this belief is (internalistically) justified, even if it does not enjoy inter subjective agreement with what externalists believe.

However, the prevalence of intersubjective disagreement in epistemology does pose a serious problem for hybrid forms of internalism and externalism; that is, for accounts of justification that not only require that all justification satisfy the accessibilist or mentalist strictures but also require for the justification of beliefs that they be produced in a reliably truth-conducive manner. These hybrids face this problem qua externalist not qua internalist.

\section{A Conciliatory Conclusion}

Having now considered, and responded to, a number of significant objections, let me conclude this article by suggesting how Internalism and Externalism may be reconciled.

Internalism and Externalism are incompatible if they are taken as offering mutually exclusive and competing accounts of the only genuine kind of epistemic justification. However, if we don't take Internalism and Externalism to be incompatible, we can affirm significant insights from each. We can do so by adopting an epistemological pluralism that recognizes more than one genuine kind of epistemic justification. Let me explain.

Externalism does indeed seem right as an account of an important kind of justification enjoyed by beliefs resulting from a doxastic process where we find a (reasonably) high degree of intersubjective agreement. In these cases, claiming that such beliefs enjoy externalist justification seems quite plausible. If these beliefs also enjoy internalist justification, then so much the better.

On the other hand, in cases of beliefs-including epistemological beliefs and philosophical beliefs more generally - where we do not find such 
intersubjective agreement, Internalism captures significant insights. In particular, it seems that the best we can plausibly claim, at least as of yet, is that such beliefs may enjoy internalist justification provided they have epistemic features (for example, coherence with our experiences and with what we believe or think we know, intuitive self-evidency, being formed in an epistemically permissible or nonculpable way, and the like) posited by Mentalism or Accessibilism.

Interestingly, Goldman for one moves in the direction of epistemic pluralism in distinguishing what he calls "strong justification" from "weak justification" and in recognizing that both are legitimate kinds of justification. His strong justification is externalistic: a belief that is strongly justified is "(roughly) a well-formed belief, a belief formed (or sustained) by proper, suitable, or adequate methods, procedures, or processes"; by contrast, his weak justification is internalistic: a belief that is weakly justified is "a faultless, blameless, or nonculpable belief" (1988, 52). What Goldman does not consider, however, is whether his belief in externalistic or strong justification, as articulated for instance in Goldman 2001, is itself externalistically or internalistically justified.

Until externalists come up with how to solve or dissolve the problem of intersubjective disagreement found in epistemological beliefs (and philosophical beliefs more generally), it appears that the best we can plausibly claim about their justificatory status - including ironically the justificatory status of the Externalist Belief itself - is that they may enjoy internalist justification. Even if, as a matter of objective fact, some epistemological beliefs - including the Externalist Belief itself - are externalistically justified, the problem of intersubjective disagreement poses a significant obstacle to plausibly claiming that they enjoy this status to any significant degree. ${ }^{8}$

Department of Philosophy and Religion

College of New Jersey

Bliss Hall 104

Ewing, NJ 08638

USA

lemorvan@tcnj.edu

\section{References}

Alston, William P. 1989. "An Internalist Externalism." In Epistemic Justification, 227-45. Ithaca, N.Y.: Cornell University Press.

- 1995. "How to Think about Reliability." Philosophical Topics 23, no. $1: 1-29$.

\footnotetext{
${ }^{8}$ Thanks to Katherine Jackson, William P. Alston, Richard Kamber, and an anonymous Metaphilosophy referee for helpful suggestions, criticisms, and challenges.
} 
Armstrong, David. 1973. Belief, Truth and Knowledge. Cambridge: Cambridge University Press.

Audi, Robert. 1989. "Causalist Internalism." American Philosophical Quarterly 26:309-20.

2001. "An Internalist Theory of Normative Grounds." Philosophical Topics 29, no. 1:19-45.

Bach, Kent. 1985. "A Rationale for Reliabilism.” Monist 68:246-63.

BonJour, Laurence. 1985. The Structure of Empirical Knowledge. Cambridge, Mass.: Harvard University Press.

Bonjour, Laurence, and Ernest Sosa. 2003. Epistemic Justification. Oxford: Blackwell.

Chisholm, Roderick. 1989. Theory of Knowledge. Third edition. Englewood Cliffs, N.J.: Prentice Hall.

- 1988. "The Indispensability of Internal Justification." Synthese 74:285-96.

. 1989. Theory of Knowledge. Third edition. Englewood Cliffs, N.J.: Prentice Hall.

Conee, Earl, and Richard Feldman. 1985. "Evidentialism.” Philosophical Studies 48:15-34.

- 2001. "Internalism Defended." In Epistemology: Internalism and Externalism, edited by Hilary Kornblith, 231-60. Oxford: Blackwell.

Dretske, Fred. 1981. Knowledge and the Flow of Information. Cambridge, Mass.: MIT Press.

Feldman, Richard. 1985. "Reliabilitiy and Justification.” Monist 68:15974.

- 2000. "The Ethics of Belief." Philosophy and Phenomenological Research 60, no. 3:667-95.

Foley, Richard. 2001. "What Am I to Believe?" In Epistemology: Internalism and Externalism, edited by Hilary Kornblith, 147-62. Oxford: Blackwell.

Goldman, Alvin 1979. "What Is Justified Belief?" In Justification and Knowledge, edited by G. S. Pappas, 1-23. Dordrecht: Reidel.

- 1986. Epistemoogy and Cognition. Cambridge, Mass.: Harvard University Press.

- 1988. "Strong and Weak Justification." Philosophical Perspectives 2:51-69.

- 2001. "Internalism Exposed." In Epistemology: Internalism and Externalism, edited by Hilary Kornblith, 207-30. Oxford: Blackwell.

- 2002. 'Experts: Which Ones Should You Trust?' In Pathways to Knowledge, 139-63. Oxford: Oxford University Press.

Goldman, Alvin, and Joel Pust. 2002. "Philosophical Theory and Intuitional Evidence." In Pathways to Knowledge, edited by Alvin Goldman, 73-94. Oxford: Oxford University Press.

Lehrer, Keith. 1990. Theory of Knowledge. Boulder, Colo.: Westview.

(C) Metaphilosophy LLC and Blackwell Publishing Ltd. 2005 
Nozick, Robert. 1981. Philosophical Explanation. Cambridge, Mass.: Harvard University Press.

Plantinga, Alvin 1993a. Warrant: The Current Debate. Oxford: Oxford Universitiy Press. Press. 1993b. Warrant and Proper Function. Oxford: Oxford University

- 2000. Warranted Christian Belief. Oxford: Oxford University Press.

Pollock, John. 1986. Contemporary Theories of Knowledge. Totowa, N.J.: Rowman and Littlefield.

Swain, Marshall. 1981. Reasons and Knowledge. Ithaca, N.Y.: Cornell University Press. 


\section{Author Query Form}

\section{Journal META \\ Article $\quad 03605011$}

Dear Author,

During the copy-editing of your paper, the following queries arose. Please respond to these by marking up your proofs with the necessary changes/additions. Please write your answers clearly on the query sheet if there is insufficient space on the page proofs. If returning the proof by fax do not write too close to the paper's edge. Please remember that illegible mark-ups may delay publication.

\begin{tabular}{|c|l|l|}
\hline $\begin{array}{c}\text { Query } \\
\text { No. }\end{array}$ & \multicolumn{1}{|c|}{ Description } & Author Response \\
\hline Q1 & No Queries. & \\
\hline & & \\
\hline & & \\
\hline & & \\
\hline & & \\
\hline & & \\
\hline & & \\
\hline & & \\
\hline & & \\
\hline & & \\
\hline & & \\
\hline & & \\
\hline
\end{tabular}

